\title{
Wash-LOCI - A Semi-Heterogeneous Version of the LOCI Technology Allowing Removal of Unbound Material After Each Assay Step
}

\author{
Fritz Poulsen \\ Novo Nordisk, \\ Denmark
}

\section{Introduction}

Pharmacokinetic (PK) studies are a crucial part of drug discovery. These studies require analysis of high numbers of plasma or serum samples from animals and humans to measure concentrations of peptide-/protein-drugs. The demands to assays are that they have a high capacity, only need low sample volumes, have a broad working range to avoid testing too many dilutions of samples, and have a good sensitivity. They have to be fast to develop and preferentially be more or less ready "on the shelf". When new drug candidates like peptides, proteins or peptide-/protein-analogues are developed it is important that assays are available to all relevant peptide-/protein-drugs in due time.

Immunoassays will often be the method of choice for this kind of testing. Especially the luminescent oxygen channeling immunoassay (LOCI) fulfill most requirements to PK testing of peptide and protein drugs (Poulsen \& Jensen, 2007). LOCI ${ }^{\mathrm{TM}}$ is a trade name of Siemens. Perkin Elmer is using the name AlphaLISA for the technology. This superior technology also has its limitations. To release the full potential of LOCI sandwich assays monoclonal antibodies (MCA) are needed due to the high percentage (100\%) of specific antibody.

It may take long time and it may be difficult to generate antibodies against relevant parts of a drug molecule and to obtain monoclonal antibodies which will cooperate in a sandwich. Developing polyclonal antibodies is much faster than developing monoclonal antibodies thus allowing faster establishment of assays. Furthermore polyclonal antibodies may contain many antibody specificities against an analyte molecule and may allow using many different species for antibody generation which may give more specificity options.

The LOCI sandwich assay requires high concentration and high density of antibodies on beads. Since the fraction of specific antibodies in a polyclonal antibody (PCA) is low (1-5\%) (Lipman et al., 2005) the density of specific antibodies on the A beads will with PCAs be reduced to $5 \%$ or less compared to MCAs. The binding capacity of SA-D beads and limitations of the SA-D bead concentrations means that high concentrations of biotinantibody is not tolerated. This means that use of PCA in LOCI which will require high concentrations of biotin-PCA to have enough specific antibody is not feasible or suboptimal. Immunopurification will thus be required to have enough specific antibodies in the assay. The immunopurification is time and resource consuming. It results in loss of antibody and 
potential loss of high avidity antibodies. Finally the antibodies may be partially denatured resulting in increased non-specific binding of the purified antibodies. To avoid this we have developed the wash-LOCI, a semi-heterogeneous LOCI version allowing direct use of high concentrations of PCA, and giving binding of a high amount of specific antibodies.

The new assay is based on the LOCI technology and is able to run with the same reagents, readers and robotic system as the normal LOCI and is only slightly more cumbersome to run than LOCI.

The wash-LOCI version allows removing non-bound biotin-PCA before addition of SA-D beads. A separation could be done by binding antibody-A beads to the well bottom, by a filtration step or by using magnetic beads (Hall et al., 1999; Koskinen et al., 2004; Kulmala et al., 2002; McCrindle et al., 1985; Namba et al., 2000; Obenauer-Kutner et al., 1997; Okano et al., 1992; Sardesai et al., 2009; Sin et al., 2006; Soukka et al., 2001). All the described methods are based on particulate labels. Since it turned out to be impossible to find 384-well filter plates with a pore size trapping the beads without being clogged by plasma this approach was given up. The LOCI A beads are not magnetic so to use magnets it would be necessary to couple the A beads to magnetic beads. The magnetic beads might give optical shielding problems and the process would be more complicated. We therefore decided to go for the version with A beads coupled directly to the well bottom.

This work was done with human insulin as a model system. Chicken plasma was used since chicken insulin cannot be measured in the assays and endogenous insulin will thus not blur the results.

The LOCI technology is based on two types of latex beads. One type, the D beads, contains a photosensitizer. The other type, the A beads, are chemiluminescent beads (Ullman et al., 1994; Ullman et al., 1996). Pairs of D beads and A beads are formed in the assay through specific binding interactions by combining sample and the two bead types. Irradiation causes photosensitized formation of singlet oxygen which migrates to and activates bound chemiluminescent beads thereby initiating a delayed luminescence emission. The basic technology is homogeneous requiring no separation and no washing. It lends itself for miniaturization to 384 allowing low sample volumes and for high capacity measurements. Run as a double antibody sandwich assay it has a very good sensitivity and a very broad working range.

The goal was to obtain usable LOCI assays based on a monoclonal and a polyclonal antibody or on a PCA pair. The PCAs must be used without immunopurification. Furthermore, the homogeneous LOCI is vulnerable to strong hemolysis or to inner filter effects or singlet oxygen quenchers in general and to hook effect at very high analyte concentrations. These limitations were tried avoided by modification of the LOCI assay. The core of this modification is anchoring the antibody-coated A-beads to the well bottom allowing wash/separation in the assay.

\section{Materials and methods}

\subsection{Plates and plate equipment}

Plates, AlphaPlate-384 High Binding (light grey) were from Perkin Elmer. Plate centrifuge, Multifuge 3 S-R Hereus. Plate washer, Tecan Power Washer 384 using wash program “cell 
wash 384_51". Plate shaker, Titramax 100 from Heidolph using speed 6. Plate reader, Envision Turbo Alpha from Perkin Elmer.

\subsection{Reagents}

Unconjugated Eu-acceptor beads (A beads) and streptavidin-coated donor beads (SA-D beads) were from Perkin Elmer.

The monoclonal antihuman insulin antibodies HUI018, HUI001, and OXI005 were from Novo Nordisk. The polyclonal guinea pig anti-insulin antisera were from Fitzgerald, Millipore, Peninsula, and Novo Nordisk. The IgG fraction from these antisera was isolated by protein A chromatography and is then referred to as Fz, Mill, Pen, and 4078E respectively.

Antibodies were coupled to A beads as described by the manufacturer except that the antibody was in $0.1 \mathrm{M}$ phosphate (sodium), $\mathrm{pH}$ 8.0, and the amount of antibody used was $0.6 \mathrm{mg} / \mathrm{mg}$ beads. The resulting product is antibody-A beads.

Biotinylation of antibodies was done as described by Poulsen \& Jensen (2007).

Human insulin was from Novo Nordisk.

Normal chicken, rat and pig EDTA plasma pools were from Bioreclamation.

\subsection{Plate coating}

Plates were coated with antibody-A beads, $35 \mu \mathrm{l} /$ well, $5 \mu \mathrm{g} / \mathrm{ml}$ in PBS pH 7.2. After addition of beads the plates were centrifuged for $2 \mathrm{~h}$ at $3452 \mathrm{xg}$ followed by incubation for $20 \mathrm{~h}$ at $4^{\circ} \mathrm{C}$. Before use the wells were washed with wash buffer and afterwards completely emptied from liquid.

\subsection{Assays}

\subsubsection{LOCI}

LOCI was performed as described previously (Poulsen \& Jensen, 2007). In brief the assay was performed in 384-well plates. Five $\mu \mathrm{l}$ of test samples were added to the wells followed by $15 \mu \mathrm{l}$ of a mixture of antibody-A beads and biotin-antibody. The plates were incubated for 1 hour at $22{ }^{\circ} \mathrm{C}$. Then $30 \mu \mathrm{l}$ of SA-D beads were added. After 30 minutes of incubation at $22^{\circ} \mathrm{C}$ the plates were measured on an Envision reader.

\subsubsection{Wash-LOCI}

The assay was performed in AlphaPlate-384 High Binding (light grey) 384-well plates.

The assay buffer contained $25 \mathrm{mM}$ Hepes, $50 \mathrm{mM} \mathrm{NaCl}, 10 \mathrm{mM}$ EDTA (tripotassium salt), 2 $\mathrm{mg} / \mathrm{mL}$ Dextran 7500 (Pharmacosmos, Holbaek, Denmark), 0.5\% bovine serum albumin (A7888; Sigma-Aldrich, St. Louis, MO), 0.1\% bovine gamma globulin (G-5009; Sigma-Aldrich), $0.2 \mathrm{mg} / \mathrm{mL}$ mouse immunoglobulin (HBR1; Scantibodies Laboratories, Santee, CA), $0.1 \%$ (w/v) Tween 20, 0.01\% Proclin 300 (Sigma-Aldrich), and $0.01 \%$ gentamycin sulphate (Biological Industries, Israel) and was adjusted to $\mathrm{pH}$ 7.4. 
Biotin-antibody buffer was assay buffer + 0.2 M Na-Citrate + $1 \%$ guinea pig serum, pH 7.40. Sample dilution buffer: Assay buffer with $0.015 \%$ (w/v) Triton X-100 and 0.05\% (w/v) SDS. Wash buffer: PBS pH 7.20 with 0.05\% (w/v) Tween 20.

The test samples and standards were diluted 1+2 in sample dilution buffer and $10 \mu \mathrm{l}$ of this ( $3.3 \mu \mathrm{l}$ plasma) were added to the wells. The plates were covered and incubated at $22{ }^{\circ} \mathrm{C}$ for 1 hour with shaking. The plates were washed on the plate washer $2 x$ with wash buffer. Biotin-antibody in biotin-antibody buffer $(10 \mu \mathrm{L})$ was then added to the wells and the plates incubated and washed as described above. Finally $10 \mu \mathrm{l}$ SA-D beads were added and the plates incubated as described above (except that it was in the dark). Immediately after this incubation the plates were read on an Envision without wash separation of unbound material utilizing the homogeneous nature of the LOCI technology.

The concentrations in wells were as follows:

Plasma sample 33\%, biotin-antibody $4.5 \mathrm{nM}$ for MCA and $80 \mathrm{nM}$ for PCA, and SA-D beads $100 \mu \mathrm{g} / \mathrm{ml}$.

The results were measured on an Envision Turbo Alpha (Perkin Elmer) with 1 detector, 70 ms excitation time and $140 \mathrm{~ms}$ detection time i.e. same adjustment for LOCI and wash-LOCI. The total processing time per 384-well plate was about 2.75 minutes, and the time for measuring from the 1 st to the last well was about 2.33 minutes.

If nothing else mentioned the standard conditions described above are used in the experiments.

\section{Results and discussion}

\subsection{Wash-LOCI principle}

The principle of the wash-LOCI is illustrated in Figure 1. Accordingly the A beads coated with antibody are attached to the bottom of the microtiter plate. After binding of insulin unbound insulin is washed away.

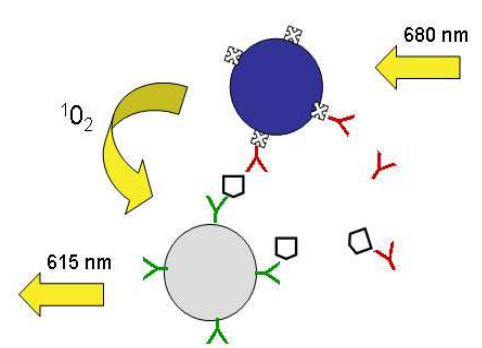

LOCI

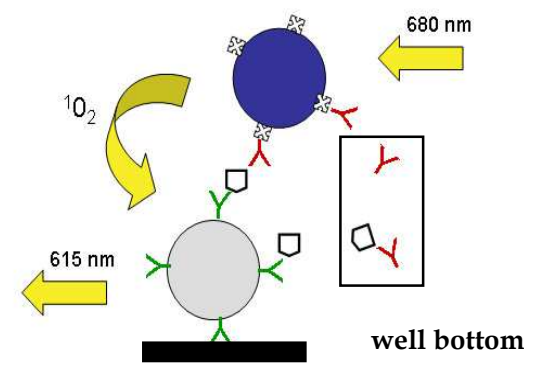

Wash-LOCI

Fig. 1. Principle of wash-LOCI and LOCI. 
This is followed by binding of biotin-antibody and again unbound molecules are washed away. The last step is addition of SA-D beads and after incubation the wells are measured in the Envision reader without washing utilizing the proximity principle of LOCI.

In this study wash-LOCI and normal LOCI are compared and from the figure it can be seen that the assays are identical except that the A beads are anchored in the wash-LOCI allowing for removal of unbound material by washing. The bead pairs are formed on the well bottom and not in suspension. This means that reading is surface reading in stead of suspension reading. To have the optimal surface to volume ratio the beads are bound to the well bottom only and not to the walls. This will also, with small sample and reagent volumes, result in faster assays. The Envision reader collects the signal from only a small part of the well bottom surface. This means that analyte bound to the bottom will be measured whereas analyte bound to the well walls will not be detected. Uniformity of the bead-coating on the bottom is crucial for this surface reading. Uniform and reproducible distribution of sample and reagents over the bottom are also important for that. The assay is run as a sequential procedure. This procedure has been found to be beneficial when a MCA/PCA sandwich is used (Obenauer-Kutner, 1997). The procedure removes analyte as well as interfering components before the biotin-antibody is added which gives a system different from and complementary to the LOCI assay.

\subsection{Coating of plates with antibody-A beads}

Coating was performed by centrifugation to secure that beads were coming into contact with the well bottom allowing them to bind.

The volume of beads for coating must have a size securing an even distribution over the well bottom. Too small bead volumes for coating will result in uneven coating. During reading the laser light from the Envision will hit the bottom and excite the $\mathrm{D}$ beads bound resulting in light output from the A beads. An uneven layer of coated A beads will thus be detrimental to the assay. Furthermore, since Envision is only exciting on the well bottom it is important that analyte and reagents are bound on the bottom.

Centrifugation is important for binding of beads by increasing the amount of beads bound and the speed of bead binding. It is important to have a high density of antibody beads on the bottom to have high antigen binding capacity. Centrifugation gave a more reproducible coating and a more uniform coating within a plate and an extra $20 \mathrm{~h}$ incubation following the centrifugation increased this positive effect. The centrifugation also prohibited or reduced the binding of beads to the walls.

For all results in this work $35 \mu \mathrm{l}$ have been used for coating but $15 \mu \mathrm{l}$ seem to work equally well. Lower volumes than $15 \mu \mathrm{l}$ should not be used since this may result in inconsistent coating. The optimal amount of beads added per well was found to be 185-370 ng/well.

Since the beads are only passively bound to the bottom the stability of this binding was tested. After coating with beads the coated plates were pretreated by incubating with assay buffer for 20 hours. The coated plates were washed before and after the incubation. Then an assay was run. No effect of this extra treatment was observed showing that the binding of the beads was strong (data not shown).

The bead-coated plates may be stored for at least 5 days at $4^{\circ} \mathrm{C}$. Plate coating is thus not considered part of the assay. 


\subsection{Wash-LOCI and LOCI with MCA and PCA}

LOCI and wash-LOCI with MCA and PCA were developed and compared.

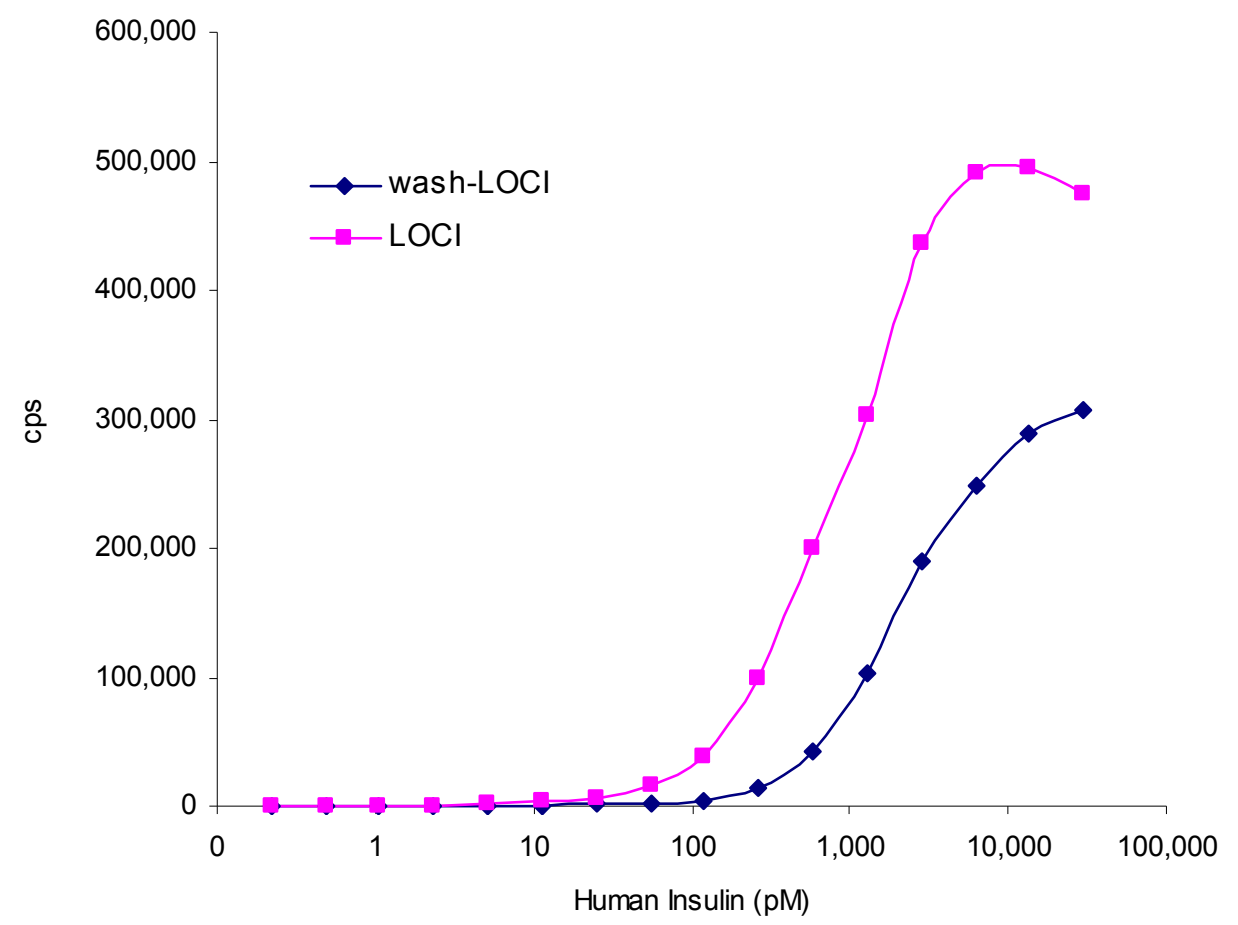

Fig. 2. Comparison of wash-LOCI and LOCI with HUI018-A beads and biotin-OXI005 in both assays.

The first characterization of the wash-LOCI was done by running LOCI and wash-LOCI with the same two MCAs (HUI018 and OXI005) used by Poulsen \& Jensen (2007). From Figure 2 it is clear that the wash-LOCI concept is working but that the LOCI assay is superior with respect to sensitivity and working range and the signal is also higher. The lower signal with wash-LOCI is probably related to the amount of HUI018-A beads per well which is higher in LOCI. On the other hand the assay performance of the wash-LOCI shows that the wash-LOCI concept is working well.

A number of sandwich combinations with MCA and PCA have been investigated in the wash-LOCI and normal LOCI. The results are illustrated in Figure 3. The MCA pair gave obviously the best LOCI assay (Fig. $3 \mathrm{C}$ ). It can be seen that MCA on the A-beads generally gave the best assays (Fig. $3 \mathrm{~A}$ and $\mathrm{C}$ ). In both assay versions PCA coupled to the A beads gave assays with lower signal, reduced sensitivity, and reduced working range (Fig. $3 \mathrm{~B}$ and D). This is ascribed to the low amount of specific antibodies in PCA which results in a lower binding capacity on the A beads. With respect to the biotin-antibody then the PCA gave lower sensitivity and range in LOCI (Fig. $3 \mathrm{C}$ ). This again must be due to a low concentration of specific antibody which can not be compensated by increasing the concentration of biotin-IgG because of a limited amount of SA-D beads (see also Fig. 9). 

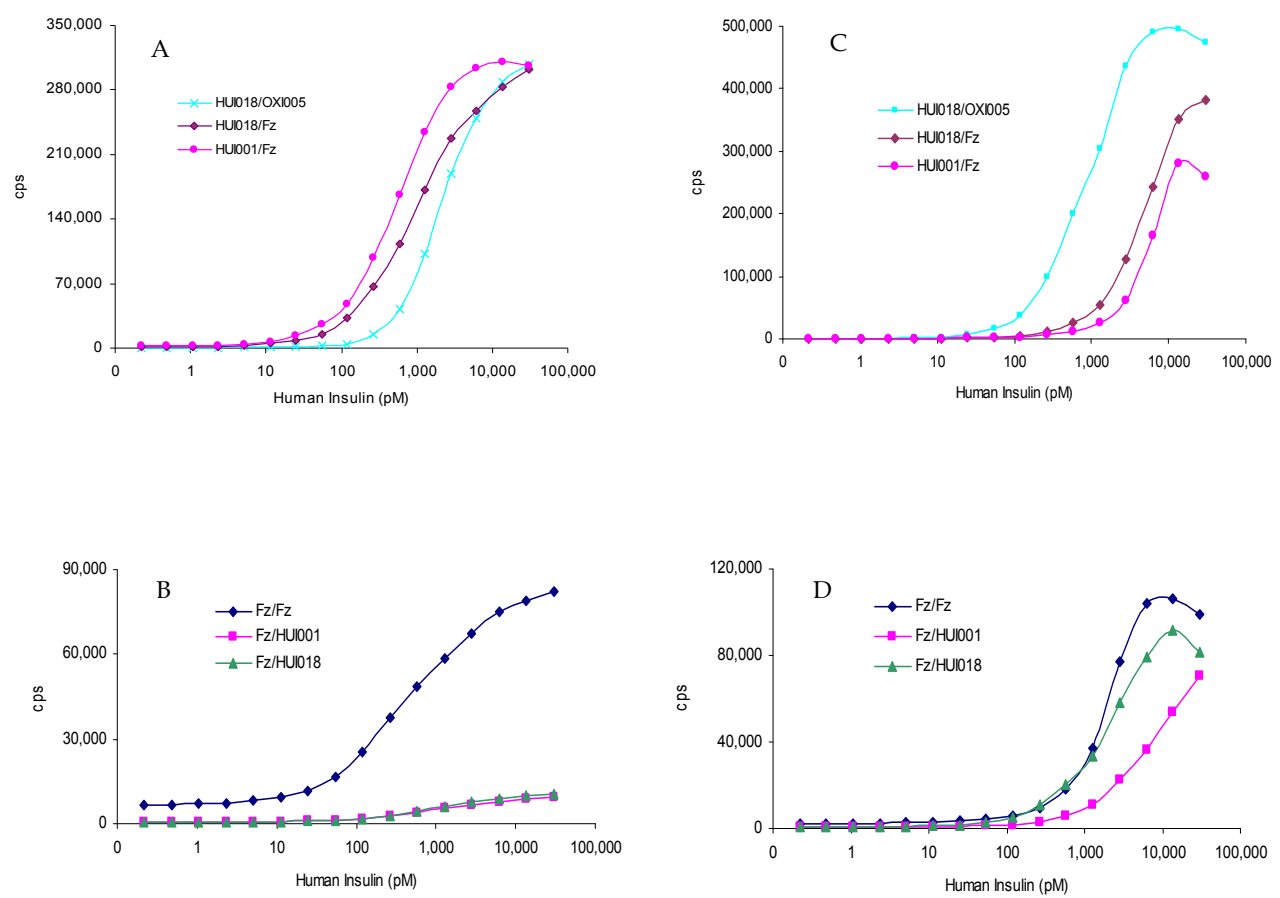

Fig. 3. Comparison of wash-LOCI (A and B) and LOCI (C and D) with various MCA and PCA combinations. The antibody pairs are shown as antibody-A bead/biotin-antibody. The same antibodies are used in the two assays for direct comparison.

The SA-D bead amount has to be limited in LOCI probably because of optical problems with too high concentrations of SA-D beads. This means that increase of the amount of biotin PCA will not be possible since it will be counter-productive (see also Fig. 9). In LOCI the excess biotin-MCA cannot be removed meaning that excess biotin-PCA will not be bound to the SA$\mathrm{D}$ beads. In wash-LOCI biotin-antibody is bound only to antibody immobilized insulin which is what has to be detected. In the wash-LOCI good assays were obtained with biotin-PCA (Fig. $3 \mathrm{~A}$ and $\mathrm{B}$ ). This is because a higher concentration of biotin PCA can be used since biotin-(nonspecific)-IgG not bound to the solid phase is washed away before addition of the SA-D beads. This result in a high amount of specific antibodies bound to insulin on antibody-A beads. The assays based on a PCA-A/biotin-MCA pair were better with LOCI than with wash-LOCI (Fig. $3 \mathrm{~B}$ and $\mathrm{D})$. This can be explained by competition between PCA and MCA for an epitope since the sequential procedure in the wash-LOCI allows the PCA to bind before the MCA is added. LOCI functioned optimally with the two MCAs whereas in the wash-LOCI the MCA-A beads with biotin-Fz gave the best results (Fig. $3 \mathrm{~A}$ and $\mathrm{C}$ ).

These data confirm that without the wash separation, immunopurification of PCAs was necessary for their use in LOCI. Otherwise the signal level will be too low, the detection 
limit too high and the working range too narrow. Omitting this purification step makes it much easier especially when many different antibodies have to be used. The wash-LOCI thus makes the use of PCAs in the LOCI technology much more feasible.

Fz was the best PCA in as well LOCI as in wash-LOCI. The LOCI assay performs well with this antibody but wash-LOCI still shows the best sensitivity with this antibody.

Comparison of wash-LOCI and LOCI with other polyclonal antibodies showed that washLOCI had a more dramatic effect with these PCAs resulting in nice wash-LOCI assays but very low sensitivity assays in LOCI (Fig. 4).
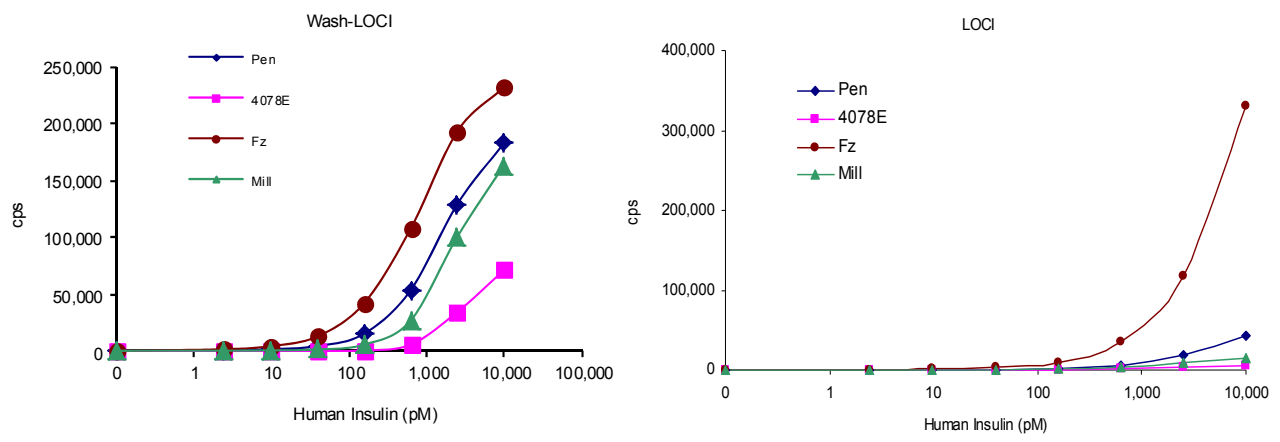

Fig. 4. Comparison of wash-LOCI and LOCI with various biotin-PCAs (Fz, Mill, Pen, and 4078E) combined with HUI018-A beads. The same antibodies are used in the two assays for direct comparison.

It can be seen that the difference between PCAs becomes smaller in wash-LOCI probably because the low PCA titre i.e. lower concentration or avidity of specific antibodies was compensated by using higher concentrations of PCA.

In Table 1 the performance of two different PCAs are shown in wash-LOCI and LOCI. It can be seen that the signal-to-noise ratio was higher with $\mathrm{Fz}$ in both assays. The wash-LOCI had higher ratios in the low concentration range whereas the LOCI had higher ratios in the high concentration range. For Mill the wash-LOCI had generally the best S/N ratios. The data indicated that the wash-LOCI had the best sensitivity with both antibodies and the broadest working range with Mill. The LOCI had the broadest working range with the best of the two PCAs i.e. Fz.

It was possible to obtain human insulin dose-response curves in LOCI with Fz with good but not necessarily acceptable sensitivity. Fz was used in this study to illustrate that it is possible to develop good LOCI assays with PCAs with high avidity/high concentration specific antibodies. The advantage of wash-LOCI was much bigger with low-titer antiinsulin PCA and with such PCAs only the wash-LOCI is working with PCA (Fig. 4).

Figure 5 (A and B) shows the best assays obtained with the two LOCI versions. It shows that with the right choice of PCA in the wash-LOCI an assay which performs comparable to our best MCA based LOCI was obtained. It was possible to run the wash-LOCI assay with PCA 
without immunopurification of the specific antibodies. Sensitivity and working range being comparable to the MCA based LOCI. The variation is smaller for the LOCI assay.

\begin{tabular}{ccccc}
\hline & \multicolumn{4}{c}{ S/N } \\
\hline Analyte & \multicolumn{2}{c}{ Wash-LOCI } & \multicolumn{2}{c}{ LOCI } \\
concentration & Fz & Mill & Fz & Mill \\
\hline 10000 & 299 & 217 & 737 & 49 \\
2500 & 249 & 134 & 263 & 33 \\
625 & 138 & 36 & 78 & 14 \\
156 & 54 & 8 & 22 & 5 \\
39 & 17 & 3 & 6 & 2 \\
10 & 6 & 1 & 2 & 1 \\
2 & 3 & 1 & 1 & 1 \\
0 & 1 & 1 & 1 & 1 \\
\hline
\end{tabular}

Table 1. Signal-to-noise $(\mathrm{S} / \mathrm{N})$ ratios calculated as the ratio between a signal and the 0 concentration signal. The assays are based on HUI018-A beads and biotin-Fz or biotin-Mill.
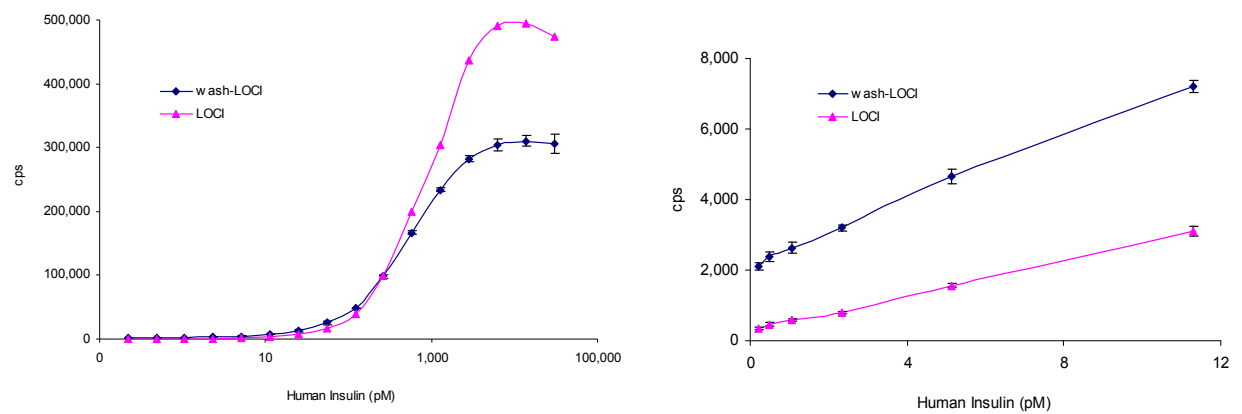

Fig. 5. Comparing optimal wash-LOCI and LOCI assays. Wash-LOCI with HUI001-A and biotin Fz and LOCI with HUI018-A and biotin-OXI005. Full concentration range, log-lin plot (left) and low concentration range, lin-lin plot (right). Data represent the mean of replicate measurements $(n=4)$ of each calibrator \pm 1 SD (error bars).

\subsection{Kinetics}

The kinetics of the wash-LOCI is due to diffusion distance in the semi-heterogeneous procedure different from the kinetics of the homogeneous LOCI. The reason for that is the diffusion distance to the immobilized beads on the bottom of the wells and the sequential nature of the wash-LOCI. However the low volume of sample and reagents in wash-LOCI and a favorable surface-to-volume ratio gave a shorter distance to diffuse; resulting in relative short assay times. 


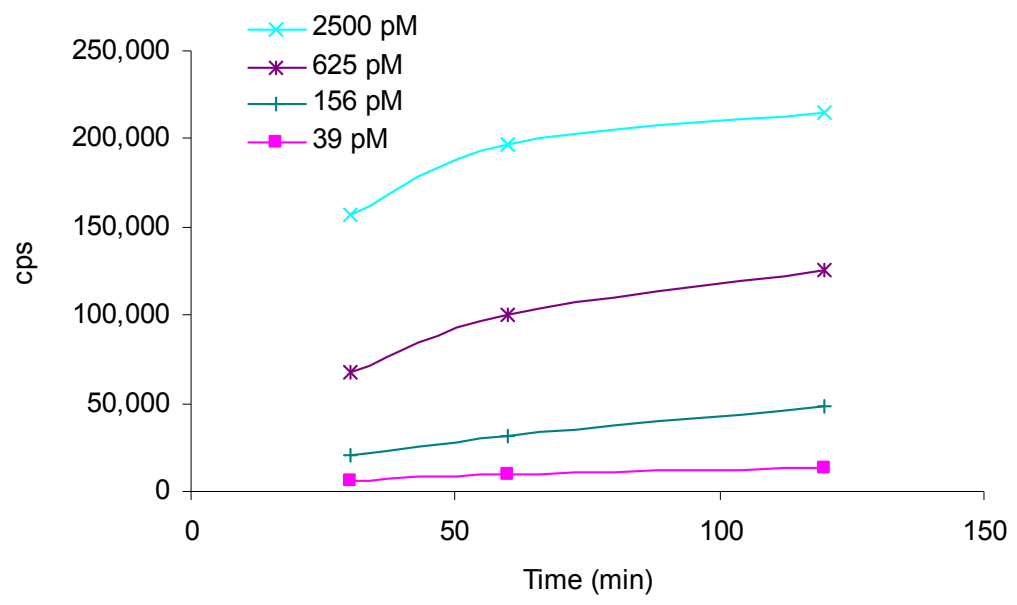

Fig. 6. Kinetics of analyte binding in wash-LOCI with the four insulin concentrations shown. The antibody pair used was HUI018-A beads/biotin-OXI005.
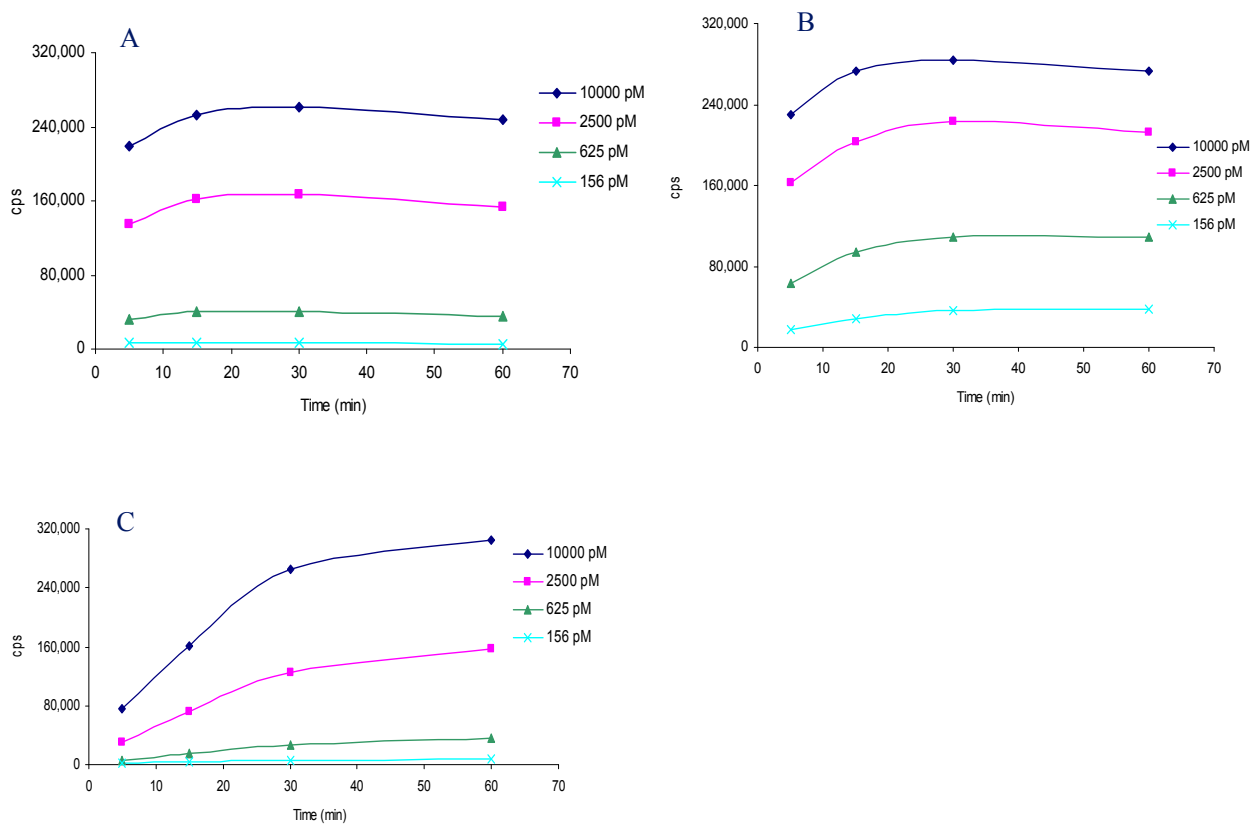

Fig. 7. Kinetics of biotin-antibody binding in wash-LOCI. HUI018-A beads with biotinOXI005 (A), biotin-Fz (B), and biotin-Mill (C). The four insulin concentrations used were as shown. 


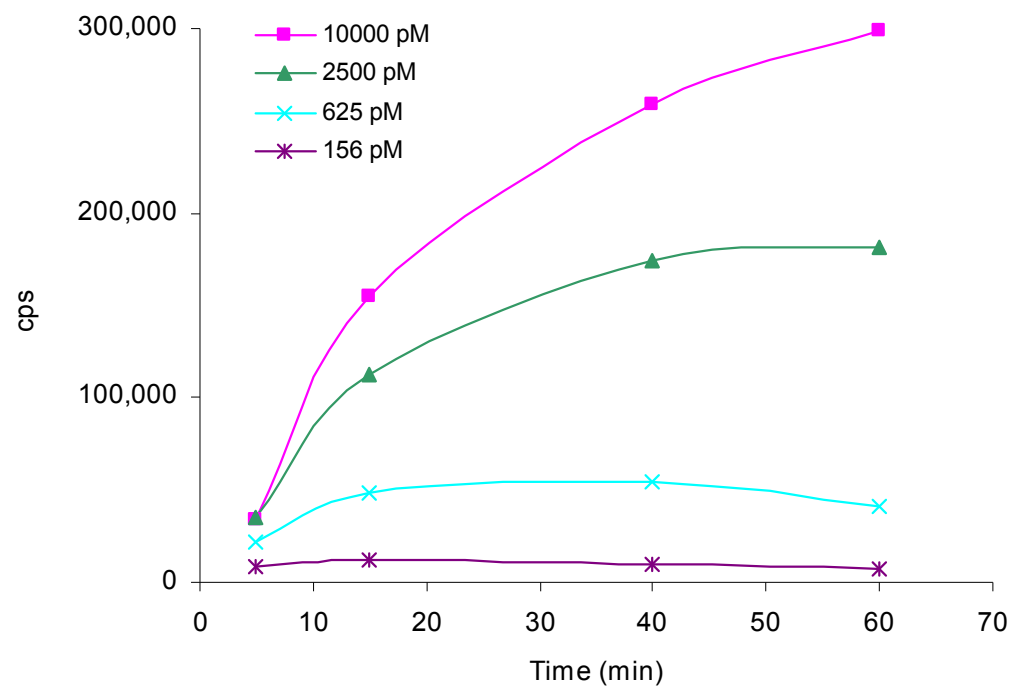

Fig. 8. Kinetics of binding of SA-D beads in wash-LOCI. The antibody pair used was HUI018-A beads/biotin-OXI005 and the four insulin concentrations used are shown.

The results of the investigation of the analyte binding are shown in Figure 6. The curves show that the analyte reaction had moved forward after 30 minutes and was still developing at 2 hours incubation. Longer incubation will give further increase in signal and improvement of sensitivity for some assays. However for practical reasons an incubation time of 1 hour was chosen. The fact that 1 hour of incubation may be needed in spite of the short diffusion distance to the bottom and in spite of the large surface-to-volume ratio may be explained by a relatively low antibody density on the bottom.

The reaction was faster at higher insulin concentrations. The antibody density was lower than in LOCI because beads bound to the well bottoms only expose part of the coupled antibodies. Furthermore fewer beads were used per well in wash-LOCI compared to normal LOCI.

Binding of biotin-OXI005 and biotin-Fz reached its maximum after 30 minutes; probably due to the high concentration of specific antibodies (Fig. $7 \mathrm{~A}$ and $\mathrm{B}$ ). The biotin-Mill was obviously much slower in accordance with lower titer of this antibody (Fig. 7 C). As a compromise for the different antibodies a reaction time of 60 minutes was chosen as the standard condition, though after 15 minutes good assays were obtained.

The kinetics of the SA-D beads was expected to be hampered by the size of the beads. The data show hat the binding of SA-D beads continued to increase from 5 minutes and to 40 minutes (Fig. 9). The reaction did not develop further between 40 and 120 minutes (data not shown). For practical reasons and since the sensitivity of the assay was better after 60 minutes, this time has been chosen as standard condition but good assays could also be obtained after 40 minutes incubation in this step.

Based on the kinetics studies it can be seen that the assay, which presently run as a 3 hours assay, can be run with a total assay time of 1.5 hours ( sample 35 minutes, biotin antibody 15 minutes and SA-D beads 45 minutes). 


\subsection{Reagent concentrations and amounts}

A sample volume of $10 \mu \mathrm{l}$ was found to be the smallest volume able to cover the well bottom.

Lower volumes will result in an uneven coating of the bottom. Higher volumes of sample will increase the reaction time. An amount of SA-D beads of $1 \mu \mathrm{g} /$ well was found to give maximum signal in wash-LOCI (data not shown). Higher concentrations of SA-D beads did not increase the signal. The maximum amount of SA-D beads in LOCI is $2 \mu \mathrm{g}$.

The effect of concentration (final) of biotin-antibodies on wash-LOCI and LOCI is shown in Figure 9. The results show that a higher concentration was required for the biotin-PCAs than for biotin-OXI005 to get maximum signal in the wash-LOCI. There was a slight increase in signal with increasing biotin-Fz concentration from $20 \mathrm{nM}$ with maximum signal and sensitivity at $80 \mathrm{nM}$. With biotin-OXI005 the maximum signal was obtained between 6.65 and $13.3 \mathrm{nM}$. With biotin-Mill the signal continued to increase up to at least $160 \mathrm{nM}$. The higher concentration needed for PCA is in accordance with the fact that only a smaller percentage of the IgG in PCA is specific antibodies. For both antibodies (Fz and Mill) 12 $\mu \mathrm{g} / \mathrm{ml}$ seemed to be suitable.
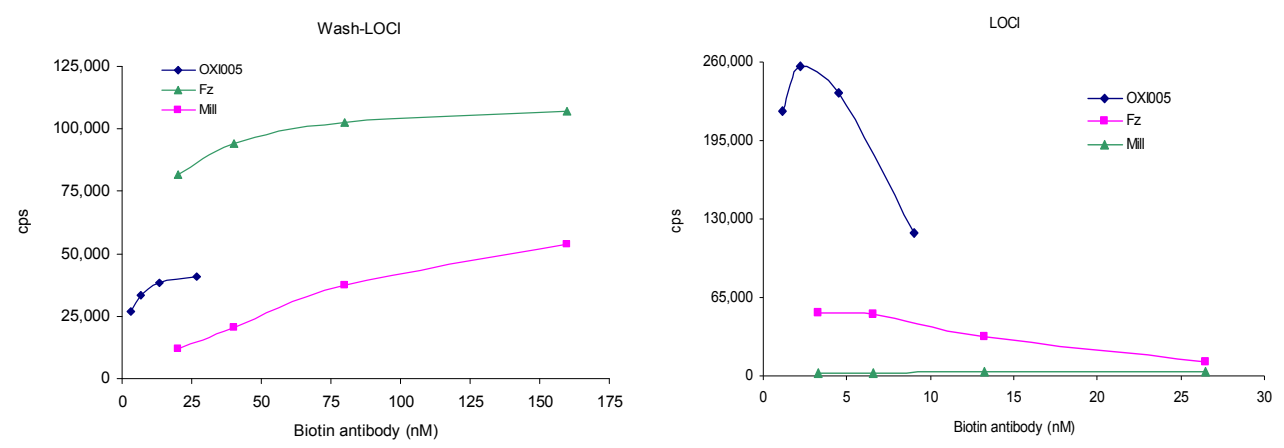

Fig. 9. Biotin-antibody concentrations in wash-LOCI and LOCI both with HUI018-A beads. The biotin-antibody concentration is shown as final concentration in a well. The insulin concentration was, in all cases, $625 \mathrm{pM}$.

It is clear that the wash-LOCI tolerated much higher concentrations of biotin-IgG than LOCI. With LOCI the signal was going down with higher concentrations of biotin-IgG.

From Figure 9 it is clear that there was an upper limit for the concentration of the biotinantibody concentration in LOCI. The reason is a limiting amount of SA-D beads. The SA-D beads can not be increased to above $2 \mu \mathrm{g}$ /well without signal reduction; probably due to optical effects. With this maximum concentration of SA-D the biotin-ab concentration should not be higher than $4.5 \mathrm{nM}$. Higher concentrations will reduce the signal. The decrease in signal was seen at the same concentration of biotin-OXI005, biotin-Fz and biotinMill. This decrease limits the application of biotin-PCA in LOCI

\subsection{Hook effect and interference}

The sequential incubations in the wash-LOCI reduced interference from plasma samples and removed the risk of hook effect at high analyte concentrations. Figure 10 shows the 
results of testing very high concentrations of insulin in wash-LOCI and LOCI. As expected there was no hook effect up to at least 100,000 pM with the wash-LOCI since excess unbound analyte was washed away prior to addition of biotin-antibody. The hook effect in the normal LOCI assays is seen at 30,000 pM. This hook effect was caused by excess insulin preventing sandwich formation. The difference between wash-LOCI and LOCI was not dramatic since LOCI has a very broad working range. However with even higher insulin concentrations the wash-LOCI has an advantage by not showing drop in signal at very high insulin concentrations.

The plasma was affecting the antigen-antibody reactions and/or the signal. This effect is shown for wash-LOCI and LOCI with chicken plasma, rat plasma pig plasma compared to assay buffer (Fig. 11). In LOCI the effect of plasma compared to assay buffer was much more pronounced. Also there was more difference between calibration curves in plasma from different species. This difference in wash-LOCI between assay buffer and plasma may be due to the effect on the antigen-antibody reaction.

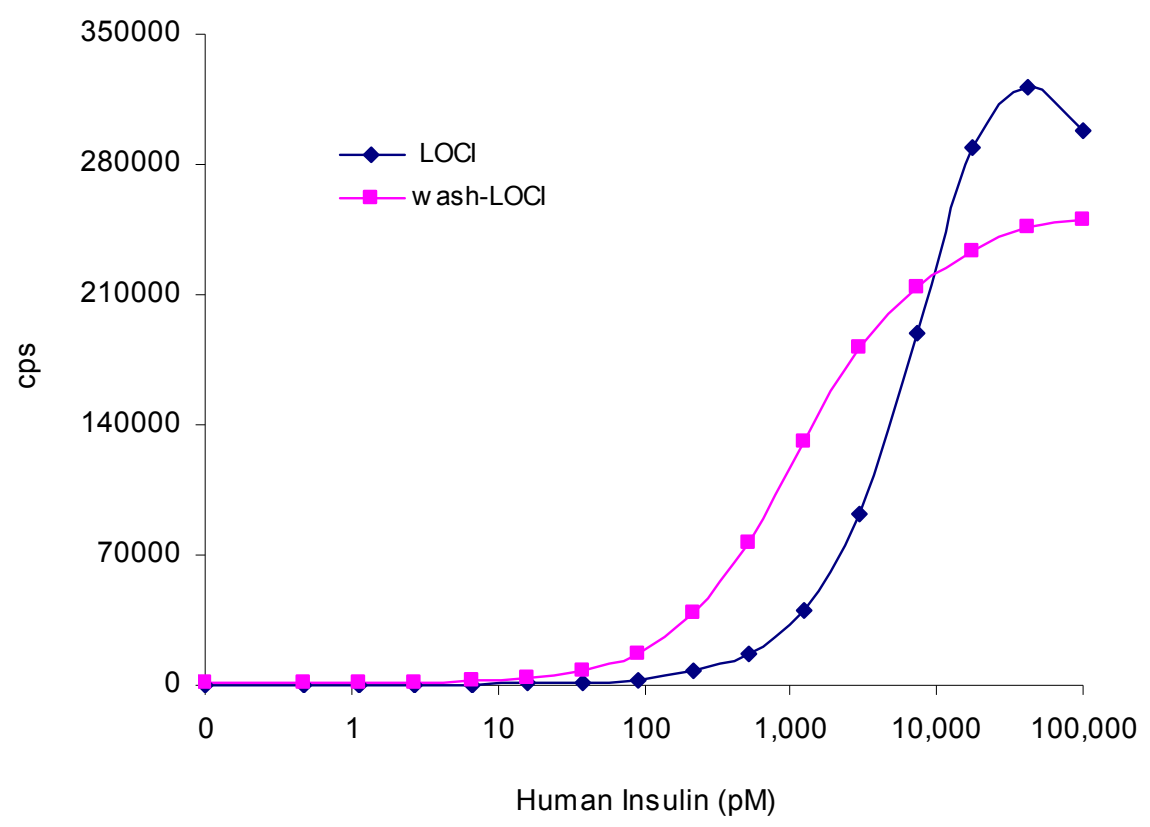

Fig. 10. Hook effect for wash-LOCI and LOCI. Antibody pairs were HUI001-A beads/biotinFz in wash-LOCI and HUI018-A beads/biotin OXI005 in LOCI. 

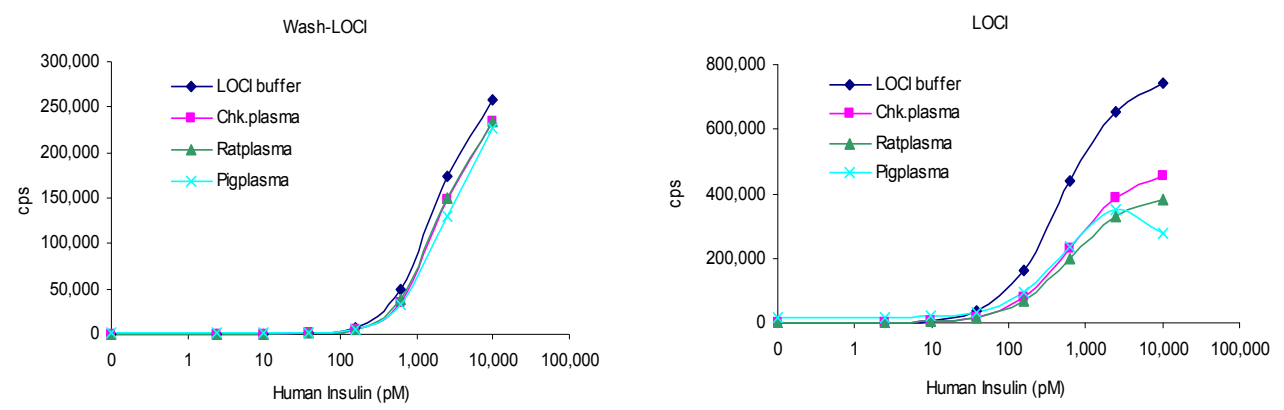

Fig. 11. Interference/matrix effects in wash-LOCI and LOCI both with HUI018-A beads/OXI005. Calibrators in assay buffer, chicken plasma, rat plasma, and pig plasma.

The effect of hemolysis is caused by quenching of singlet oxygen and is thus affecting the signal output. This is in accordance with the limited effect in wash-LOCI compared to LOCI (Table 2).

\begin{tabular}{cccc}
\hline \multicolumn{2}{c}{ Wash-LOCI } & \multicolumn{2}{c}{ LOCI } \\
\hline Hemoglobin(mg/dl) & \% Recovery & Hemoglobin(mg/dl) & \% Recovery \\
\hline 0 & 100 & 0 & 100 \\
94 & 94 & 94 & 92 \\
187 & 97 & 187 & 82 \\
375 & 97 & 375 & 80 \\
750 & 87 & 750 & 74 \\
1500 & 82 & 1500 & 61 \\
3000 & 75 & 3000 & 46 \\
\hline
\end{tabular}

Table 2. Interference from hemoglobin in plasma. The assays were run with HUI018-A beads and biotin-OXI005. A chicken plasma sample spiked with $800 \mathrm{pM}$ human insulin and with hemolysate of human erythrocytes to give the hemoglobin concentrations shown.

It can be seen that the wash-LOCI tolerated up to $1500 \mathrm{mg}$ hemoglobin/ $\mathrm{dl}$ compared to 375 $\mathrm{mg} / \mathrm{dl}$ for the LOCI assay. The results with removal of hemolysate interference by washing show that the wash-LOCI may be used for samples containing interfering components. The wash-LOCI was more robust to plasma effect, singlet oxygen quenchers and inner filter effects. Only one of the antigen-antibody reactions was directly affected since plasma was washed away before the biotin-antibody was added and all plasma components were washed away before measurement. 


\subsection{Plate uniformity}

Reproducibility studies were performed by running a plate with the same sample (1000 pM of human insulin in chicken plasma) in all wells except for the two calibrator columns 11 and 12 . The variation in signal was $3.8 \%$ and there were no marked patterns on the plate. The wash-LOCI is more prone to variation than the homogenous version due to the plate coating and washing steps. It is important that the plate washer is washing all wells exactly the same way and that no or very little wash fluid is left in the wells.

\section{Conclusion}

This study has shown that the traditional homogeneous LOCI assay can be converted into a new semi-heterogeneous wash-LOCI which includes wash separation. Human insulin was used as a model analyte. LOCI and wash-LOCI were based on the same reagents and equipment. The only difference being that the antibody coated A-beads were anchored to the bottom of the plate wells in wash-LOCI. This anchoring allows introducing wash steps which will render the LOCI technology even more versatile. The assay worked (due to wash after biotin-antibody incubation) with not-immunopurified PCA. It was performed with the two antigen-antibody reactions as separate steps followed by addition of SA-D bead i.e. a sequential assay. Due to wash after sample incubation this assay was less prone to sample interferants. The signal was measured directly from the bottom of the well.

Wash-LOCI assays showed very good sensitivity and a broad working range. It worked with low plasma sample volume ( $3 \mu \mathrm{l}$ per well). The assay has a high capacity and may be run with the same equipment and on the same robotic lines as LOCI. With PCA and washLOCI it may be possible to measure molecules which can not be measured in existing MCA/MCA assays.

Wash-LOCI should be seen as a supplement to LOCI. It is very easy to switch from the no wash version to the wash version. However the normal LOCI is much easier to run and is a better assay so the wash-LOCI should only be considered for special purposes.

The LOCI technology thus has the potential for non-separation-based (no-wash) and separation-based (wash) immunoassays.

\section{Acknowledgements}

The author thanks Kirsten Borres Jensen for excellent technical assistance and valuable discussions.

\section{References}

Hall, M.; Kazakova, I. \& Yao, Y.-M. (1999). High Sensitivity Immunoassays Using Particulate Fluorescent Labels. Analytical Biochemistry, Vol. 272, pp.165-170, ISSN 0003-2697

Koskinen, J.O.; Vaarno, J.; Meltola, N.J.; Soini, J.T.; Hänninen, P.E.; Luotola, J; Waris, M.E.\& Soini, A.E. (2004). Fluorescent nanoparticles as labels for immunometric assay of Creactive protein using two-photon excitation assay technology. Analytical Biochemistry, Vol. 328, pp.210-218, ISSN 0003-2697 
Kulmala, S.; Håkonson, M.; Spehar, A.-M.; Nyman, A.; Kankare, J; Loikas, K.; Ala-Kleme, T. \& Eskola, J. (2002). Homogeneous and heterogeneous electrochemiluminescence assays of TSH at Disposable Oxide-Covered aluminum electrodes. Analytica Chimica Acta, Vol. 458, 271-280, ISSN 0003-2670

Lipman, N.S.; Jackson, L.R.; Trudel, L.J. \& Weis-Garcia, F. (2005). Monoclonal versus polyclonal antibodies: Distinguishing Characteristics, Applications, and Information Resources. Institute for Laboratory Animal Research Journal, Vol.46, 3, pp. 258-268, ISSN 1084-2020

McCrindle, C.; Schwenzer, K. \& Jolley, M.E. (1985). Particle Concentration Fluorescence Immunoassay: A New Immunoassay Technique for Quantification of Human Immunoglobulins in serum. Clinical Chemistry. Vol 31, (9), pp.1487-1490, ISSN 00099147

Namba, N.; Sawada, T. \& Suzuki, O. (2000). Development of High Sensitivity Ru-Chelate Based ECL Immunoassay 2: Electrochemical and Immunochemical Studies on Homogeneous and Heterogeneous ECL Excitation. Analytical Sciences, Vol.16, pp.757-763, ISSN 0910-6340

Obenauer-Kutner, L.J.; Jacobs, S.J.; Kolz, K.; Tobias, L.M. \& Bordens, R.W. (1997). A Highly Sensitive Electrochemiluminescence Immunoassay for Interferon alpha- $2 b$ in human serum. Journal of Immunological Methods, Vol. 206, 25-33, ISSN 0022-1759

Okano, K.; Takahashi, S.; Yasuda, K.; Tokinaga, D.; Imai, K. \& Koga, M. (1992). Using Microparticle Labelling and Counting for Attomole-Level Detection in Heterogeneous Immunoassay. Analytical Biochemistry, Vol 202, 120-125, ISSN 00032697

Poulsen, F \& Jensen, K. B. (2007). A Luminescent Oxygen Channeling Immunoassay for the Determination of Insulin in Human Plasma. Journal of Biomolecular Screening, 12, (2), 240-247, ISSN 1087-0571

Sardesai, N.; Pan, S. \& Rusling, J. (2009). Electrochemiluminescent immunosensor for detection of protein cancer biomarkers using carbon nanotube forests and [Ru(bpy) 3 ]-doped silica nanoparticles. Chemical Communication (Cambridge). Vol 7, (33), 4968-4970, ISSN 0959-9428

Sin, K.-K.; Chan, C.P.-Y.; Pang, T.-H.; Seydack, M. \& Renneberg, R. (2006). A highly sensitive fluorescent immunoassy based on avidin-labelled nanocrystals. Analytical and Bioanalytical Chemistry. Vol. 384, 638-644, ISSN 1618-2642

Soukka, T; Antonen, K.; Härmä, H.; Pelkkikangas, A.-M.; Huhtinen, P. \& Lövgren, T. (2003). Highly sensitive immunoassay of free prostate-specific antigen in serum using europium(III) nanoparticle label technology. Clinica Chimica Acta,Vol. 328, 45-58, ISSN 0009-8981

Ullman, E.F.; Kirakossian, H.; Singh, S.; Wu, Z.P.; Irvin, B.R.; Pease, J.S.; Switchenko, J.D.; Irvine J.D.; Dafforn, A.; Skold, C.N. \& Wagner D.B. (1994). Luminescent oxygen channelling immunoassay : measurement of particle binding kinetics by chemiluminescence. Proceedings of the National Academy of Sciences USA. Vol. 91, 5426-5430, ISSN 0027-8424

Ullman, E.F.; Kirakossian, H.; Switchenko, A.C.; Ishkanian, J.; Ericson, M.; Wartchow, C.A.; Pirio, M.; Pease,J.; Irvin, B.R.; Singh, S.; Singh, R.; Patel, R.; Dafforn, A.; Davalian, D.; Skold, C.; Kurn, N. \& Wagner, D.B. (1996). Luminescent oxygen channelling assay (LOCI): Sensitive, broadly applicable homogeneous immunoassay method. Clinical Chemistry. Vol. 42, (9), 1518-1526, ISSN 0009-9147 


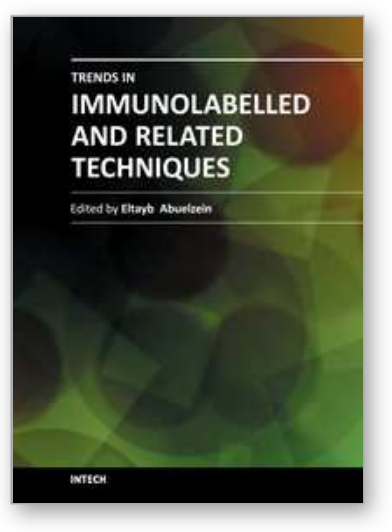

\author{
Trends in Immunolabelled and Related Techniques \\ Edited by Dr. Eltayb Abuelzein
}

ISBN 978-953-51-0570-1

Hard cover, 360 pages

Publisher InTech

Published online 27, April, 2012

Published in print edition April, 2012

The book is coined to provide a professional insight into the different trends of immunoassay and related techniques. It encompasses 22 chapters which are grouped into two sections. The first section consists of articles dealing with emerging uni-and-multiplex immunolabelled methods employed in the various areas of research. The second section includes review articles which introduce the researchers to some immunolabelled techniques which are of vital significance such as the use of the conjugates of the Staphylococcus aureus protein "A" and the Streptococcus Spps. protein "G" in immunolabelled assay systems, the use of bead-based assays and an overview on the laboratory assay systems. The book provides technological innovations that are expected to provide an efficient channel for developments in immunolabelled and related techniques. It is also most useful for researchers and post-graduate students, in all fields, where immunolabelled techniques are applicable.

\title{
How to reference
}

In order to correctly reference this scholarly work, feel free to copy and paste the following:

Fritz Poulsen (2012). Wash-LOCI - A Semi-Heterogeneous Version of the LOCI Technology Allowing Removal of Unbound Material After Each Assay Step, Trends in Immunolabelled and Related Techniques, Dr. Eltayb Abuelzein (Ed.), ISBN: 978-953-51-0570-1, InTech, Available from: http://www.intechopen.com/books/trendsin-immunolabelled-and-related-techniques/wash-loci-a-semi-heterogeneous-version-of-the-loci-technologyallowing-removal-of-unbound-material

\section{INTECH}

open science | open minds

\section{InTech Europe}

University Campus STeP Ri

Slavka Krautzeka 83/A

51000 Rijeka, Croatia

Phone: +385 (51) 770447

Fax: +385 (51) 686166

www.intechopen.com

\section{InTech China}

Unit 405, Office Block, Hotel Equatorial Shanghai

No.65, Yan An Road (West), Shanghai, 200040, China

中国上海市延安西路65号上海国际贵都大饭店办公楼405单元

Phone: +86-21-62489820

Fax: $+86-21-62489821$ 
(C) 2012 The Author(s). Licensee IntechOpen. This is an open access article distributed under the terms of the Creative Commons Attribution 3.0 License, which permits unrestricted use, distribution, and reproduction in any medium, provided the original work is properly cited. 